\title{
Business Strategy and Enterprises' Ability of Sustainable Development: Evidence from China
}

\author{
Xuan Xie \\ School of Management \\ Sichuan Agricultural University \\ Chengdu, China \\ E-mail: 183677525@qq.com
}

\author{
Tianqiao Feng \\ School of Management \\ Sichuan Agricultural University \\ Chengdu, China \\ E-mail: fengtianqiao@qq.com
}

\author{
Yunchen Wang* \\ School of Management \\ Sichuan Agricultural University \\ Chengdu, China \\ E-mail: wangyc8684@qq.com \\ *Corresponding Author
}

\begin{abstract}
The present study was designed to investigate whether business strategy affects firms' ability of sustainable development. Using a sample of A-share non-financial publicly listed firms in China, this paper shows that: (1) on average, there is a negative correlation between the choice of radical strategy and the sustainable development ability of enterprises; (2) compared with non-high-tech enterprises, the above relation is more pronounced in high-tech enterprises. The findings are also robust to endogeneity checks and alternative measures of firms' sustainable development ability. Overall, this study indicates that business strategy plays a fundamental role in enterprise operations, and the choice of radical strategy will weaken the sustainable development ability of enterprises, especially in hightech enterprises. Therefore, this study suggests that in order to improve the sustainable development ability of enterprises, it is necessary to further optimize the strategic choice of enterprises and avoid using too many radical strategic types.
\end{abstract}

Keywords-Business Strategy; Sustainable Development Ability; High-Tech Enterprises

\section{INTRODUCTION}

The sustainable development of enterprises is a new research perspective formed with the combination of the sustainable development theory and the enterprise management theory. This line of research focuses more on the long-term development ability of enterprises. The sustainable development ability of an enterprise refers to the ability that an enterprise can not only ensure its market position and achieve its business objectives in current, but also maintain its competitive advantages and sustainable profits in a relatively long time.

For enterprises, the sustainable development capacity of

National Social Science Foundation Project of China: "Research on the path and guarantee mechanism of Party committee governance function of the state-owned enterprises under the situation of the power restriction of managers " (18CGL016) and the project of Sichuan Rural Development Research Center: "Study on the financial management evaluation and policy optimization of farmers' professional cooperatives in the perspective of Rural Revitalization"(CR1818) economy, environment and society are interdependent. How to improve the ability of sustainable development to achieve the goal of the enterprise is closely related to the strategic choice of the enterprise, since enterprise strategy is an essential part of firms' internal environment and every aspect of major decision making, which plays an important role in setting up sustainable organization structure and management practices. For example, the more radical the corporate strategy is, the more decentralized the corporate control structure is, and it will lead to a more complex coordination mechanism, resulting in more serious information asymmetry.

Therefore, whether the radical strategy will weaken enterprises' ability of sustainable development? Does the above relationship vary in different industries? After quickly reviewing the views of the firm and strategy selecting literature and using the theoretical business strategy framework, this paper examines the relationship between a firm's business strategy selecting and its sustainable development. We first investigate whether a firm's business strategy is associated with its sustainable developing ability. Next, we analyze the influence of strategic choice on their sustainable development ability in high-tech enterprises and non-high-tech enterprises. Comparing with the previous researches, the main conclusions and contributions of this study including: (1) This paper enriches the relevant research on the influencing factors of enterprises' sustainable development ability. Previous research is mainly focused on the macro factors to promote the sustainable development ability of enterprises, but they pay less attention to the driving force behind these factors. This paper finds that the more radical the enterprise's strategy is, the lower its sustainable development ability is, which enriches research of the consequences of the enterprise's strategy; (2) This paper provides direct evidence to support that it is of great significance to promote high-tech enterprises to formulate and implement appropriate corporate strategies and enhance their sustainable development ability. The empirical evidence shows that the strategic types selected by high-tech enterprises have a 
more significant impact on their sustainable development ability than those in non-high-tech enterprises.

\section{ThEORETICAL ANALYSIS AND RESEARCH HypOTHESES}

First, according to the sustainable development ability of enterprises, the existing researches are respectively from the three dimensions of environment, economy and society. In the economic dimension, sustainable development at the enterprise level is closely related to the choice of business strategy. If an enterprise wants to improve its long-term viability, it needs to penetrate the concept of building a sustainable enterprise into all aspects of its business through the formulation of strategic level. Miles and Snow (1978, 2003) divide corporate strategy into three types: radical, analytical and defensive. This kind of strategy type can be measured by archival data, so it can be used to study corporate strategy in a larger sample range.

It has been found that in the financial field, the more radical the strategy, the lower the quality of information disclosure, and the higher the audit cost. In addition, compared with the companies adopting defensive strategy, the companies adopting radical strategy have higher risk of stock price collapse and higher probability of financial fraud [4, 6].Generally, enterprises will improve their management skills and risk prevention abilities by selecting a stable development strategy to enhance their sustainable development ability. Aggressive enterprises have greater risk of poor performance. Compared with defensive enterprises, aggressive enterprises focus more on developing new products and new markets, regardless of the uncertain output. Especially when coupled with over-confident management, overinvestment is a more severe issue in aggressive firms. Therefore, the radical strategy will bring negative economic benefits to enterprise behavior and hinder the sustainable development of the enterprise [1]. Base on the analysis above, this study poses the hypothesis 1 : under the premise of the same condition, compared to regular enterprises, enterprises that choose more radical strategies have weaker sustainable development ability.

High tech enterprises have the characteristics of high investment, so they need to maintain high investment to carry out new product research and technological innovation, so it is very important for them to maintain stable $R \& D$ investment. And those enterprises implement the innovation strategy tend to adopt the low financial leverage to reduce the pressure of debt paying. The lower leverage can help them to maintain and enhance the core competitive advantage, so as to obtain sustainable development ability. As for enterprises adopting radical strategies, which are often accompanied with high financial leverage may result in less sustainable development ability. Therefore, referring to the previous analysis, this study put forward the hypothesis 2: under the premise of the same condition, compared with other non-high-tech enterprises, the negative correlation between radical strategy and sustainable development ability is more significant in high-tech enterprises.

\section{RESEARCH DESIGN}

\section{A. Sample Selection and Data Sources}

In this paper, A-share non-financial listed companies from 2007 to 2016 in China are selected as the initial samples, after eliminating ST or PT and companies of which data is severely missing, the final sample of 15821 observations is then analyzed. In identifying samples of high-tech enterprises, we selected totally four industries which are computer, communication and other electronic equipment manufacturing industries, software and information technology service industries, railway, ship and aerospace and other transportation equipment manufacturing industries and pharmaceutical manufacturing industries according to the notice made by Ministry of science and technology, the Ministry of Finance and the State Administration of Taxation about the "measures for the administration of the determination of high-tech enterprises "and the relevant provisions of the "state key supported high-tech fields". The data is all from CSMAR database. In order to eliminate the influence of extreme values, all continuous variables were tailed at the level of $1 \%$ and $99 \%$.

Referring to Bentley, Omer and Sharp (2013), this paper constructs the following discrete variables to measure the strategic types of Chinese enterprises [5]. This variable mainly focuses on the following six characteristics of enterprises: (1) Importance of developing new products. This paper uses Ratio of R\&D expenditures to sales. (2) Attention paid to the operation efficiency of the enterprise. This paper uses Ratio of the number of employees to sales. (3) Growth of the company. This paper uses one-year percentage change in total sales. (4) Importance of product market development. This paper uses Ratio of SG\&A expenses to sales. (5) Organization stability. This paper uses SD of the total number of employees. (6) Technical efficiency. This paper measured as net property, plant, and equipment scaled by total assets. The above variables are computed over a rolling prior five-year period. In each annual sample, they are divided into five groups from small to large. For the first five variables, they are given a score of 1 to the minimum group, and given 2 to the second minimum group, and so on. For the sixth variable, they are given a score of 5 to the maximum group and given 4 to the second maximum group and so on. For each observation of "company year", the group scores of six variables are summed up, and finally, the measurement variable strategy with a value range of 6-30 is obtained. The value of the defensive strategy is between $6-12$, the value of the analysis strategy is between 1323, and the value of the radical strategy is between 24-30.

The sustainable development ability of an enterprise refers to its long-term profitability and long-term competitiveness. In this paper, according to Van Horne's static model of sustainable development [3], the sustainable development index of an enterprise is constructed to measure the sustainable development ability of a listed company.

\section{B. Test Model and Illustration of relevant variables}

We use logistic regression to determine whether the business strategy is associated with sustainable development ability. Our model is as follows with subscripts omitted: 
and we expect $\beta 1$ to be larger in high-tech samples than that in non-high-tech samples.

The definition of each variable including the control variables is shown in Table I.

We expect $\beta 1$ to be significantly negative. Then we divide the whole sample into high-tech and non-high-tech enterprises,

$+\beta_{6}$ ROA $+\beta_{7}$ Growth $+\beta_{8}$ Idratio $+\beta_{9}$ Top $1+\beta_{10}$ Dual $+\beta_{11}$ State $+\beta_{12}$ Age $+\varepsilon$

TABLE I.

The Definitions of Main VARIables

\begin{tabular}{|c|c|c|}
\hline Variable & Symbol & Variable Definition \\
\hline $\begin{array}{l}\text { Dependent } \\
\text { Variable }\end{array}$ & Sustain & $\begin{array}{c}\text { net sales interest rate * retained earnings rate } *(1+\text { equity Ratio }) /(1 / \text { turnover rate of total assets - net sales interest rate } * \\
\text { retained earnings rate } *(1+\text { equity Ratio })\end{array}$ \\
\hline $\begin{array}{l}\text { Independent } \\
\text { Variable }\end{array}$ & Strategy & Refer to Bentley et al. (2013) for the construction of discrete score, refer to more detail in the previous description \\
\hline \multirow{11}{*}{ Control Variable } & CF & Net cash flow from operating activities divided by total assets \\
\hline & Margin & Operating margin \\
\hline & Size & Natural logarithm of total assets \\
\hline & Lev & Financial leverage equal to total debt divided by total assets \\
\hline & ROA & Return on assets equal to income before extraordinary items divided by total assets \\
\hline & Growth & Percentage change in sales from the prior year to the current year \\
\hline & Idratio & Number of independent directors divided by total number of directors \\
\hline & Top1 & Proportion of the largest shareholder \\
\hline & Dual & Indicator variable equal to 1 if the chairman and the CEO in a firm is the same person during the year and 0 otherwise \\
\hline & State & Indicator variable equal to 1 if the firm is a state-owned enterprise and 0 otherwise \\
\hline & Age & Length of time in years the firm has been publicly listed \\
\hline
\end{tabular}

\section{TESt Results AND ANALyses}

\section{A. Descriptive statistics}

TABLE II. The Descriptive Statistics of MAIN VARIABLES

\begin{tabular}{|c|c|c|c|c|c|c|}
\hline Variables & $\boldsymbol{N}$ & Mean & Median & SD & Min & Max \\
\hline Sustain & 15821 & 0.075 & 0.072 & 0.174 & -0.814 & 0.755 \\
\hline Strategy & 15821 & 16.711 & 17.000 & 3.871 & 6.000 & 30.000 \\
\hline CF & 15821 & 0.045 & 0.041 & 0.508 & -4.270 & 62.790 \\
\hline Margin & 15821 & 0.265 & 0.229 & 0.174 & -0.043 & 0.809 \\
\hline Size & 15821 & 21.849 & 21.716 & 1.255 & 18.933 & 25.735 \\
\hline Lev & 15821 & 0.457 & 0.451 & 0.227 & 0.046 & 1.164 \\
\hline ROA & 15821 & 0.036 & 0.034 & 0.060 & -0.233 & 0.220 \\
\hline Growth & 15821 & 0.203 & 0.104 & 0.616 & -0.651 & 4.809 \\
\hline Idratio & 15821 & 0.370 & 0.333 & 0.052 & 0.300 & 0.571 \\
\hline Top1 & 15821 & 0.353 & 0.333 & 0.152 & 0.088 & 0.753 \\
\hline Dual & 15821 & 0.229 & 0.000 & 0.420 & 0.000 & 1.000 \\
\hline State & 15821 & 0.363 & 0.000 & 0.481 & 0.000 & 1.000 \\
\hline Age & 15821 & 14.421 & 14.000 & 5.196 & 2.000 & 27.000 \\
\hline
\end{tabular}

The descriptive statistics for our samples are presented in Table II, including separate descriptive statistics for companies following high-tech enterprises and non-high-tech enterprises. The descriptive statistics of the main variables are seen in Table II. The mean value of sustain is 0.075 and the median is 0.072 , indicating that the actual sustainable development ability of many enterprises is less than the expected sustainable development ability; the SD is 0.174 , indicating that there are significant differences in the sustainable development ability of different enterprises. The SD of enterprise strategy is 3.871, which shows that the strategic types of sample enterprises are significantly different.

\section{B. Regression Analysis}

TABLE III. THE REgRESSION TEST ON SUSTAIN

\begin{tabular}{|c|c|c|c|}
\hline \multirow{3}{*}{ Variables } & \multicolumn{3}{|c|}{ Dependent variable: Sustain } \\
\hline & (1) & $(2)$ & (3) \\
\hline & Whole Sample & High-technology & Non-High-tech \\
\hline \multirow{2}{*}{ Strategy } & $-0.002 * * *$ & $-0.003 * * *$ & $-0.001 * * *$ \\
\hline & $(-4.425)$ & $(-3.860)$ & $(-4.296)$ \\
\hline \multirow{2}{*}{$\mathrm{CF}$} & $0.021 * * *$ & $0.017 * * *$ & $0.090 * * *$ \\
\hline & $(8.581)$ & $(8.762)$ & $(7.299)$ \\
\hline \multirow{2}{*}{ Margin } & 0.018 & $0.045^{* * *}$ & $0.017 * * *$ \\
\hline & $(1.413)$ & $(2.721)$ & $(3.884)$ \\
\hline \multirow{2}{*}{ Size } & $0.017 * * *$ & $0.019 * * *$ & $0.017 * * *$ \\
\hline & $(8.530)$ & $(6.700)$ & $(15.885)$ \\
\hline \multirow{2}{*}{ Lev } & -0.003 & 0.024 & -0.005 \\
\hline & $(-0.229)$ & $(1.580)$ & $(-0.761)$ \\
\hline \multirow{2}{*}{ ROA } & $1.680^{* * * *}$ & $1.325^{* * *}$ & $1.704^{* * *}$ \\
\hline & $(28.969)$ & $(24.167)$ & $(74.521)$ \\
\hline \multirow{2}{*}{ Growth } & $0.034 * * *$ & $0.039 * * *$ & $0.034 * * *$ \\
\hline & $(6.223)$ & $(9.402)$ & $(17.407)$ \\
\hline \multirow{2}{*}{ Idratio } & 0.013 & 0.065 & 0.009 \\
\hline & $(0.702)$ & $(1.297)$ & $(0.423)$ \\
\hline \multirow{2}{*}{ Top1 } & $0.018 * *$ & -0.015 & $0.020 * *$ \\
\hline & $(2.507)$ & $(-0.790)$ & $(2.567)$ \\
\hline \multirow{2}{*}{ Dual } & $0.008^{* * * *}$ & $0.015^{* *}$ & $0.006^{* *}$ \\
\hline & $(2.860)$ & $(2.512)$ & $(2.198)$ \\
\hline \multirow{2}{*}{ State } & $-0.007 * *$ & 0.003 & $-0.008 * * *$ \\
\hline & $(-2.538)$ & $(0.364)$ & $(-3.064)$ \\
\hline \multirow{2}{*}{ Age } & 0.000 & -0.001 & 0.000 \\
\hline & $(1.267)$ & $(-1.116)$ & $(1.547)$ \\
\hline \multirow{2}{*}{ Constant } & $-0.344 * * *$ & $-0.386 * * *$ & $-0.338 * * *$ \\
\hline & $(-9.662)$ & $(-6.369)$ & $(-14.833)$ \\
\hline $\mathrm{Chi}^{2}$ statistics & & $3.280^{*}$ & \\
\hline Observations & 15821 & 2119 & 13702 \\
\hline Adjusted $\mathrm{R}^{2}$ & 0.430 & 0.388 & 0.437 \\
\hline
\end{tabular}

a. Figures in the table are estimated coefficient and t statistics are revised by Robust standard

b. $* * *, * *, *$ Significant at $1 \%, 5 \%$, and $10 \%$ levels respectively.

Table III presents the regression results from estimating model (1), the coefficient of strategy is -0.0015 , which is significantly negatively related to the sustainable development 
ability of the enterprise at the level of $1 \%$, indicating that the enterprise selecting radical strategy will significantly reduce the sustainable development ability of the enterprise, and hypothesis 1 is verified. In order to further examine the impact of the strategic choice of high-tech enterprises on sustainable development ability, we grouped the samples according to the two categories of high-tech enterprises and non-high-tech enterprises. The coefficients of strategy are both significant in the two groups ( $p<0.01$ ), but the coefficients of Strategy is larger in high-tech enterprises than those in non-high-tech enterprises, and the difference is significant at the level of $10 \%$, so hypothesis 2 is verified.

\section{Robust Test}

TABLE IV. RoBust Test Results

\begin{tabular}{|c|c|c|c|}
\hline \multirow{2}{*}{ Variables } & \multicolumn{3}{|c|}{ Dependent variable } \\
\hline & Sustain1 & Sustain2 & Sustain \\
\hline \multirow[t]{2}{*}{ Strategy } & $-0.001^{* * *}$ & $-0.001 * * *$ & \\
\hline & $(-4.510)$ & $(-5.688)$ & \\
\hline \multirow[t]{2}{*}{ L_Strategy } & & & $-0.002 * * *$ \\
\hline & & & $(-5.135)$ \\
\hline \multirow[t]{2}{*}{ Constant } & $-0.230 * * *$ & $-0.232 * * *$ & $-0.364 * * *$ \\
\hline & $(-7.365)$ & $(-8.201)$ & $(-9.739)$ \\
\hline $\begin{array}{c}\text { Observati } \\
\text { ons }\end{array}$ & 15821 & 15821 & 15627 \\
\hline $\begin{array}{c}\text { Adjusted } \\
\mathrm{R}^{2}\end{array}$ & 0.508 & 0.443 & 0.429 \\
\hline
\end{tabular}

In order to test the robustness of the empirical results of our study, we use Higgins' sustainable growth model (Sustain1) and the index of sustainable growth rate in CSMAR database (Sustain2) to replace sustain in the previous section. According to the regression results in Table IV, the results are basically the same as those before the replacement, so our findings are robust to alternative measures of firms' sustainable development ability. Moreover, since this paper studies the influence of enterprise strategy and sustainable development ability, and there may be endogenous problems between enterprise strategy and sustainable development ability, so we deal with the explanatory variables in the later stage of regression analysis, and can alleviate the endogenous problems to a certain extent through Lead-Lag Approach. The test results are shown in Table IV, and the main conclusions have not changed, indicating that the research in this paper is not severely affected by endogeneity, and the research conclusions are relatively stable.

\section{CONCLUSION}

Based on the strategic theory and sustainable development theory, this paper studies the influence of radical strategy on the sustainable development ability of enterprises and further classifies enterprises into high-tech enterprises and non-hightech enterprises. Using a sample of A-share non-financial listed companies in China from 2007 to 2016, this paper draws the following conclusions: the more radical the enterprise strategy is, the lower the sustainable development ability of the enterprise is. Among them, compared with other non-high-tech enterprises, the enterprises engaged in high-tech show a more significant correlation in the impact of radical strategy on the sustainable development ability of enterprises.

In conclusion, the evidence presented in this paper suggests that it is important to pay attention to the strategic types that enterprises choose when considering the factors that affect their sustainable development of enterprises. It can help the board of directors to realize the relationship between enterprise strategy and sustainable development ability and assist them to make more appropriate strategic choices, especially for high-tech enterprises. In addition, for the investors who are willing to make a long-term investment in the enterprises with strong sustainable development ability, it would be useful to pay more attention to the business strategy the enterprise selects.

\section{ACKNOWLEDGMENT}

We are deeply grateful for the support from the project of the National Social Science Foundation of China and the project of Sichuan Rural Development Research Center.

\section{REFERENCES}

[1] B. Q. Wang, C. R. Hou and J. Sun, "Research on the impact of corporate strategy on corporate performance,” China Soft Science, vol. 1, pp.127-137, 2018. (In Chinese)

[2] D. Higgins, T. C. Omer, and J. D. Phillips, "The influence of a firm's business strategy on its tax aggressiveness," Contemporary Accounting Research, vol. 32(2), pp. 674-702, 2015.

[3] J. C. Van Horne, "Sustainable Growth Modeling," Journal of Corporate Finance, vol. 8, pp.19-25, 1988.

[4] J. Sun, B. Q. Wang and F. Cao, "Does the company's strategy affect the risk of stock price collapse?” Economic Management, vol. 38(12), pp. 47-61, 2016. (In Chinese)

[5] K. A. Bentley, T. C. Omer and N. Y. Sharp, "Business strategy, financial reporting irregularities, and audit effort," Contemporary Accounting Research, vol. 30(2), pp. 780-817, 2013.

[6] Y. F. Ai, M. H. Tong and G. L. Sun, "Corporate strategy, large shareholder shareholding and financial fraud," Financial Theory and Practice, vol. 38(4), pp.70-76, 2017. (In Chinese) 